\title{
Generic Skills and the Employability of Electrical Installation Students in Technical Colleges of Akwa Ibom State, Nigeria.
}

\author{
Caleb, E. C And Udofia, A.E (Ph.D) \\ Department of Vocational Education Faculty of Education University of Uyo, Uyo. Akwa Ibom State
}

\begin{abstract}
Generic skills are key competencies that can be used across a large number of different occupations and they provide a platform for the development of employability skills needed by young people and adults. This study investigated the influence of generic skills on the employability of Electrical Installation and maintenance students in Technical Colleges of Akwa Ibom State. It employed the survey research design, 3 research questions and 2 null hypotheses guided the study. A total of 60 Electrical Installation students drawn from a population of 80 students were randomly stratified to form the sample. The researchers developed instrument tagged "electrical Installation employability indices" (EIEI) was used for data collection. The instrument was face and content validated and the reliability index was established at .89 using the test retest method. The statistical tools used for the study were mean and Analyysis of Variance (ANOVA). The research findings reveal that Electrical Installation students possess essential generic skills and it was concluded that the generic skills have an influence on their employability. It was recommended that lecturers emphasize the importc generic skills and they should also encourage group discussions in classrooms.
\end{abstract}

Keywords: generic skills, employability, TVET, Electrical Installation and maintenance

\section{Introduction}

The global economy has evolved into a knowledge based economy, where skills and human resources have become the driving force for innovation, continued growth and corporate competitive advantage. The meaning and the practice of work in the new knowledge based economy is changing and the need for highly skilled and productive workforce is shaping economies worldwide. To increase their chances of employability, Electrical Technology students need skills that are flexible and relevant to the demands of today's industry. In the past, Electrical Technology Education focused on imparting hard or technical skills, which include technical or administrative procedures related to an organization's core business like machine operation, safety standards and procedures (Coates, 2006). However, increasing industrial complexity has shifted focus to coordination and communication. Beyond job specific competencies, a set of skills which are generic to a cluster of occupations is required for effective participation in the knowledge based economy. Thus, employers are putting more weight on generic skills (Firth, 2011).

Kearns (2001) defines generic skills as key competencies that can be used across a large number of different occupations and they provide a platform for the development of employability skills needed by young people and adults. Generic skills involve little or no interaction with machines, but help individuals maintain positive social relationships and contribute to the work environment. Key generic skills include communication and interpersonal skills, problem solving skills, using your initiative and being self-motivated, working under pressure and to deadlines, organisational skills, team working, ability to learn and adapt, using mathematical ideas and techniques, using technology, valuing diversity and difference and negotiation skills. These skills are independent of sector, underpin technical skills and draw on personal attributes. However, the extent by which these skills need to be possessed varies from one occupational grouping to another.

Technical and Vocational Education and Training (TVET) students are expected to have well developed technical skills as well as generic skills that allows for flexibility, adaptability and ability to work across a range of jobs. Participation in the new knowledge based economy characterised by dynamic work environments and changing job descriptions, require generic skills for adaptability and relevance. TVET system in Nigeria must help students go beyond taking up immediate employment, to having high level of employability that will enable graduates to adapt to the demands of various jobs throughout a lifetime. Brown and Hesketh (2004) define employability as the relative chances of getting and maintaining different kinds of employment. Beyond this definition, employability further entails the capability of an individual to gain and maintain employment. It further shows where one stands relative to others on the job continuum. For individuals, employability depends on their knowledge, skills and abilities.

Central to employability is a solid foundation on generic skills. For an individual, employability skills connote the broad range of proficiencies which he or she needs to secure, keep a job and to progress in a career. But a major concern for graduates is what constitutes employability skills as the skills possessed by graduates 
seem to be different from what employers are looking for. Employers often outline a set of skills that they want from an employee. These skills are what they believe will equip the employee to carry out their role to the best of their ability.

Central to developing employability is generic skills. Generic skills act as the interface for the development of technological skills, aiding in the adaptation to new work conditions and development of new skills while on the job

\section{Problem Statement}

Today's organizations are characterized by changing, dynamic environments in which the need for adaptive workers has become increasingly important (Smith, Ford, \& Kozlowski, 1997).Technological industries are continually searching for innovative solutions. They place emphases on employees being able to think analytically, organise and plan effectively, and reflect on outcomes. The ability to find solutions to problems using creativity, reasoning, team work and past experiences are often very valuable. There is widespread concern that schools are failing to impart the kind of skills that employers need, furthermore, that certain generic skills have grown in importance in the new knowledge based economy, requiring swift response and sustained attention from educators and administrators to ensure that graduates of Universities maintain employability.

There are also concerns raised on the essential generic skills taught to electrical technology students, how they are embedded in the curriculum and the methods of assessment. Embedding a skill in an activity without explicitly recognising it may minimise its transfer. Few attempts have been made to ascertain the essential generic skills taught to electrical technology students in Universities in Rivers State, the method of transfer and assessment. Generic skills are either imparted through training or experiences and interactions (Baher, 2010). However, while these skills are implied by the curriculum, they are not transferred to students using both formal and informal ways. Generic skills are difficult to measure and the faculty have not considered alternative methods of assessment of the extent of the development of generic skills. However, there have been few attempts to investigate the degree of usage of such core skills and other generic skills, nor their association, if any, with labour market rewards (Ali and Frederickson, 2006).

\section{Purpose of the Study}

The purpose of this study is to determine the influence of generic skills possessed by Electrical Installation and Maintenance students in Technical Colleges of Akwa Ibom State on their employability. Specifically, the objectives were

1. To ascertain the extent of generic skills possessed by Electrical Installation and maintenance students in Technical Colleges in Akwa Ibom state.

2. To ascertain methods of assessment of generic skills by Teachers in Technical Colleges in Akwa Ibom state.

3. To determine the appropriate strategies in promoting the development of generic skills in Electrical Installation and maintenance students in Technical Colleges in Akwa Ibom state.

\section{Research Questions}

1. What is the influence of generic skills possessed by Electrical Installation and maintenance students on their employability?

2. How are Teachers assessing students on the development of generic skills?

4. What appropriate strategies can be used to promote the development of generic skills by Electrical Installation and maintenance students in Technical Colleges in Akwa Ibom state.

\section{Null Hypotheses}

1. The is no significant influence of the generic skills possessed by electrical technology students on their employability

2. There is no significant difference in the mean score of girls and boys on the extent of generic skills possessed

\section{Significance of the Study} employers.

The findings of this study would be of immense importance to the students, governments and

The study would reveal to the students the skills demanded by employers that they (the students) are supposed to posses as they prepare for the world of work. The study would also benefit the government at all levels, as it furnishes the government with relevant data and information in their effort in to improve the delivery of certain generic skills lacking in some sections of the workforce. The employers of labour also stand 
to gain from the findings of the study as it would further reveal to them the areas of strength and weaknesses of prospective employees. It would further help them in designing training programmes to compensate for any perceived weakness in new and prospective employees.

\section{Theoretical Framework}

Job Competition Theory

The theoretical framework for this study can best be explained by the Job competition theory. Thurow (1975) proposed a theory of job competition which stipulates that based on attained schooling, workers are ranked in order of trainability and the highest ranked worker is assigned to the highest ranked job. Leuven and Oosterbeek (2011) stated that the implication of this is that higher educational attainment raises the possibility of being employed. Consequently, people go for more skills so as to be employable.

Alternatively, the job-competition model of Thurow (1975) considers two queues: a job queue and a person queue. Each job in the job queue has its own skill requirements and productivity characteristics. Individuals competing for jobs also form a queue, their relative position in the queue are determined by a set of characteristics such as education and experience that suggest to the employer the cost of training them in the skills necessary to perform a given job. The higher a person is in the person queue, the less is the cost of training and the more likely the person will be to get a job at the head of the job queue. Thus, in order to place themselves higher up in the person queue, individuals will invest in education and training, hoping that an additional amount of skills will enhance their chances of getting a good job relative to others.

In view of the fact that well educated individuals are easier to train, and the costs involved are therefore lower, these individuals are in front of the labour queue. Instead of competing against each other based on wages, individuals compete for jobs based on background characteristics. The foremost of such characteristics is the level of skills possessed. To stand any chance in the highly competitive labour market using the job queue theory, a job seeker has to acquire more skills to be able to move up the job queue ladder and increase his chances of being employed. Technology is not just creating new occupations, it is also creating new sets of skills. These skills created by technology and demanded by industries require adaptability to develop. Central to employability and the development of technological skills is generic skills. A job seeker who can multi task, solve problems, take initiatives, communicate effectively, work collaboratively in a team setting, has apparently placed his/her self higher in the job queue and employability index. The more of these skills they posses, the higher their position in the job queue, thus, the higher their employability.

\section{Design of the Study}

\section{II. .Research Method}

A survey design was adopted for the study. The design was considered suitable for the study as it employs the study of a small sample to make inference on a larger population.

\section{Area of the Study}

The study area was all public Technical Colleges in Akwa Ibom state. The choice of these institutions was informed by the fact that they offer TVET programmes.

\section{Population of the Study}

The population size is 500 Electrical Installation and Maintenance students. The target population of this study comprised of all Electrical Installation and Maintenance students in the six public Technical Colleges of Akwa Ibom State.

\section{Sampling and Sampling Techniques}

The total of 300 students constituted the sample size for the study. The stratified random sampling technique was used in selecting respondents (males and females) and cutting across students in all levels.

\section{Instrument for Data Collection}

A structured questionnaire tagged "Electrical Installation and Employability Indices" (EIEI) was constructed by the researchers for the purpose of this study. It consisted of five points likert scale of response options with keys provided to elicit answers to the items accordingly. Students were asked to rate the generic skills which they taught were important and the extent practiced in their institution using the keys provided for the response options.

\section{Validation of the Instrument}


The instrument was face and content validated by three experts. Two experts from the Department of Vocational Education and an expert from Measurement and Evaluation all in the University of Uyo, Akwa Ibom State, were involved in the validation process.

\section{Reliability of the Instrument}

A test-retest procedure was employed to establish the reliability coefficient of the instrument. The instrument was administered to fifty respondents drawn from the population but not part of the study. The said instrument was administered to the same group after two weeks interval. Pearson product moment correlation coefficient was used to establish the relationship between the test and retest scores. The reliability coefficient index was .89 .

\section{Administration of the Instrument}

The researchers personally administered the instrument to the students and also collected them.

\section{Method of Data Analysis}

The mean was used to answer the research questions while the hypotheses were tested using the Analysis of Variance (ANOVA).

\section{Decision Rule}

The mean was used to answer the research questions. A mean of 3.4 and above is accepted. The hypotheses will be answered using the Analysis of Variance. Where the calculated $\mathrm{F}$ is higher than the significance value at $\mathrm{P}<.05$, the null hypothesis is rejected. Where the calculated $\mathrm{F}$ is less than the significance value at $\mathrm{P}<.05$, the null hypothesis is accepted.

\section{Data Presentation and Discussion}

Research Question 1: What is the influence of generic skills possessed by Electrical Installation and Maintenance Works students on their employability?

Table 1

Generic Skills Practiced by Electrical Technology Students

\begin{tabular}{|l|l|l|l|}
\hline Items & Identified Generic Skills & $\overline{\boldsymbol{X}}$ & Decision \\
\hline 1 & Communication and interpersonal skills & 3.4 & Agreed \\
\hline 2 & Being able to use mathematical ideas and techniques & 3.0 & \\
\hline 3 & Being able to solve problems & 3.4 & Agreed \\
\hline 4 & Being able to use information technology & 3.5 & Agreed \\
\hline 5 & Being able to collect, analyse and organise information & 3.4 & Agreed \\
\hline 6 & Ability to learn and adapt & 3.5 & Agreed \\
\hline 7 & Team working skills & 3.4 & Agreed \\
\hline 8 & Being creative and innovative in work & 3.4 & Agreed \\
\hline 9 & Being able to plan and organise activities & 3.3 & Agreed \\
\hline 10 & Being adaptable to change at work & 3.4 & Agreed \\
\hline
\end{tabular}

Analysis of data presented in Table 1 shows the extent of practice of generic skills among electrical Installation and Maintenance Works students in Technical Colleges of Akwa Ibom State. The data reveals that the students all agreed that all ten generic skills are emphasized by the school. Being able to use ICT and ability to learn and adapt were the most outstanding, with mean scores of 3.5 each.

Research Question 2: How are lecturers assessing students on the development of generic skills?

Table 2

Methods of Assessing Generic Skills

\begin{tabular}{|l|l|l|l|}
\hline $\begin{array}{l}\text { Item } \\
\text { No }\end{array}$ & Item description & $\overline{\boldsymbol{X}}$ & Decision \\
\hline 11 & The teacher divides the class into groups during instruction sometimes & 3.0 & \\
\hline 12 & Students sometimes comment on the efforts of other students & 3.0 & \\
\hline 13 & Students are assessed on -the- spot by teachers after an activity & 3.2 & \\
\hline 14 & Teachers use play-acting sometimes in class & 3.3 & \\
\hline 15 & Mini projects are given by teachers & 3.7 & Agreed \\
\hline 16 & Outside evaluation by other teachers other than my teacher & 3.0 & \\
\hline
\end{tabular}


From Table 2, the data reveals that only mini project had a mean score of 3.7 and thus, is the only alternative method of assessment practiced. All other items had mean scores below 3.4 which was the benchmark mean.

Research Question 3: What appropriate strategies can be used to promote the development of generic skills by electrical technology students in Technical Colleges of Akwa Ibom State?

Table 3

Strategies for advancing generic skills provision in electrical technology in Technical Colleges of Akwa Ibom State KEY- Strongly Agree (SA), Agree (A), Undecided (U), Disagree (D) and Strongly Disagree (SD)

\begin{tabular}{|l|l|l|l|}
\hline $\begin{array}{l}\text { Item } \\
\text { No }\end{array}$ & Item description & $\overline{\boldsymbol{X}}$ & Decision \\
\hline 17 & Provision of separate modules for teaching generic skills & 3.5 & Agreed \\
\hline 18 & $\begin{array}{l}\text { Better promotion by teachers of the importance of generic } \\
\text { skills }\end{array}$ & 3.7 & Agreed \\
\hline 19 & $\begin{array}{l}\text { More explicit profiling of generic skills within the training } \\
\text { packages }\end{array}$ & 3.5 & Agreed \\
\hline $\begin{array}{l}\text { Improvements on how generic skills are explained and } \\
\text { assessed }\end{array}$ & $\begin{array}{l}\text { Critical analysis and emphasis on the importance and } \\
\text { practice of generic skills by teachers }\end{array}$ & 3.4 & Agreed \\
\hline 21 & Professional/ adaptability skills development of teachers & 3.4 & Agreed \\
\hline 22 & Continued industry involvement in training & 3.7 & Agreed \\
\hline 23 & Updating of existing training packages & 3.4 & Agreed \\
\hline 24 & & \\
\hline
\end{tabular}

Table 3 reveals that all items considered as strategies for improving the development of generic skills were agreed to by the respondents. A close look at the data shows that continued industry involvement and better promotion by teachers of the importance of generic skills had the highest mean scores and were thus, the most outstanding strategies for promoting the development of generic skills.

\section{Hypotheses Testing}

Null Hypothesis 1:There is no significant influence of the generic skills possessed by Electrical Technology students on their employability.

Table 4

Summary of Testing Results for Null Hypothesis 1

\begin{tabular}{|l|l|l|l|l|l|}
\hline Source & $\begin{array}{l}\text { Sum } \\
\text { Squares }\end{array}$ & Df & Mean Square & F & Sig. \\
\hline Between Groups & 81 & 1 & 81 & $5.563^{*}$ & .026 \\
\hline Within Groups & 406 & 28 & 15 & & \\
\hline Total & 487 & 29 & & & \\
\hline
\end{tabular}

*significant at $\mathrm{P}<.05$

Table 4 indicates that the calculated F-value is 5.563 with the significant of $\mathrm{F}$ at .026 . This means that, at $\mathrm{P}<$ .05 , the null hypothesis is not significant. Therefore the null hypothesis stating that there is no significant influence of the generic skills possessed by electrical technology students on their employability is rejected and the alternate hypothesis is accepted. Thus, there is significant influence of generic skills on the employability of electrical technology students in rivers state university of science and technology.

Null Hypothesis 2: There is no significant difference in the mean score of girls and boys on the extent of generic skills possessed.

Table 5

Summary of Testing Results for Null Hypothesis 2

\begin{tabular}{|l|l|l|l|l|l|}
\hline Source & $\begin{array}{l}\text { Sum of } \\
\text { Squares }\end{array}$ & df & Mean Square & F & Sig. \\
\hline Between Groups & 384 & 1 & 384 & $14.092 *$ & .001 \\
\hline Within Groups & 763 & 28 & 27 & & \\
\hline Total & 1147 & 29 & & & \\
\hline
\end{tabular}

* significant at $\mathrm{P}<.05$ 
Table 5 indicates that the calculated $\mathrm{F}$-value is 14.092 with the significant of $\mathrm{F}$ at .001 . This means that, at $\mathrm{P}<$ .05 , the null hypothesis is not significant. Therefore the null hypothesis stating that there is no significant difference in the mean score of girls and boys on the extent of generic skills possessed is rejected and the alternate hypothesis is accepted. Thus, there is significant difference in the mean scores of boys and girls with respect to the extent of the development of generic skills.

\section{Discussion of Findings}

The findings of the study reveal that Electrical Installation and maintenance students in Technical Colleges of Akwa Ibom State possess essential generic skills to a great extent. This findings agree with Imeokparia and Ediagbonya (2012) that Technical and Vocational Education and Training (TVET) students have high employability skills, differ significantly with sex and were also lacking in some core skills as indicated by the low mean scores.

The results of this study also agreed that separate modules be used to teach generic skills, promotion by teachers of the importance of soft skills, updating of existing training packages, continued industry involvement in training, Improvements on how generic skills are explained and assessed and professional skills development of teachers were all strategies for promoting functional education skills acquisition by students.

This study also agree with Clayton, (2002) which opined that there is need for strategies for helping teachers to identify, promote, assess and certify generic skills. Thus, there is need to update existing training packages.It further indicated that there is need for effective professional development of TVET teachers, greater industry participation and fruitful exchanges between industries and TVET practitioners and trainers.

The findings reveal that teachers are not using the alternative forms of assessment in assessing students' development of generic skills. This findings is in consonance with the report of Jane (2012), that the faculty is rather obsessed about measuring everything-course completions, test scores, etc. With generic skills comes the need to think about new ways of measuring success. Learning per se should not be measured in an organizational context, it is the new performance that it brings about. Sometimes that can be measured by a positive change in speed or output or productivity, sometimes not. Sometimes it is important to just recognize the other intangible benefits that occur.

\section{Conclusion}

The evolving and dynamic work environment of the knowledge based economy has serious implications for skills training in technological education. to enter and make progress in the world of work and to keep abreast of changes in job descriptions, electrical technology students need to develop generic skills to increase their employability. People with better technical (hard) skills and employability skills stand a better chance of being employed in the new knowledge based economy where adaptability is key.

\section{Recommendations}

From the findings of the study, the following recommendations are made

1. Teachers should stress the importance of generic skills to students

2. The teacher should consider group discussions for some sections of the learning experience to help build confidence, communication and group efforts

3. Information and communication technologies should be introduced into instruction.

\section{References}

[1]. Ali S., \& Frederickson, N. (2006). Investigating the evidence base of social stories. Educational Psychology in Practice, 22(4), 35577.

[2]. Clayton, B. (2002. July $\left.10^{\text {th }}-12^{\text {th }}\right)$. Impacting on policy and practice: implications of assessment research. Paper presented at the $11^{\text {th }}$ national VET research conference, Brisbane.

[3]. Coates, D. E. (2006) People Skills Training: Are you getting return on investment? Performance Support Systems, Retrieved 2 March 2011 from http://www.praxisconsulting.org /PeopleSkills.pdf.

[4]. Firth, M. (2011).What job skills are employers looking for today? Retrieved from http://www.suite101.com/content/what-job-skillsare-employers-looking-for-today-a282039\#ixzz1CWcHpHQy

[5]. Imeokparia, P. \& Ediagbonya, K. (2012). Employability of business education graduates. International Research Journals, 3(8), 645651

[6]. Jane, H.(2012). Instructional design and e-learning. Retrieved from www.thelearningcoach.com/elearning2.0/social-media-andlearning/

[7]. Kearns, P. (2001). Generic Skills for the New Economy. Australia: National centre for vocational education and research.

[8]. Leuven, E. \& Oosterbeek, H., (2011). Overeducation and mismatch in the labour market. Institute for the study of labour (Iza). Discussion Paper No. 5523 February 2011.

[9]. Smith, E. M., Ford, J. K., \& Kozlowski, S. W., (1997). Building adaptive expertise: Implications for training design. In M. A. Quinones and A. Dudda (Eds.). Training for 21st century technology: Applications of psychological research. Washington, DC: APA Books. 
[10]. Thurow, L. (1975) Generating Inequality: Mechanisms of Distribution in the U.S. Economy. New York: Basic Books.

\section{Appendix}

\section{Instrument for Data Collection}

The questionnaire titled "Generic skills and Employability Indices" is meant to collect information from you. Your responses will be used for academic purposes you are not required to write your name, but please let your responses agree with your facts

INSTRUCTION

Please you are required to respond to all the items in this questionnaire you are expected to indicate the extent of your agreement to the items by ticking $\square \square$ any of the options represented by the following Abbreviations

Name of your

PART A- PERSONAL INFORMATION

University.

.....

Year in school: Year 1

Gender:

Age group:

Male

$16-20$

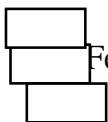

Year 2

emale

$21-25$

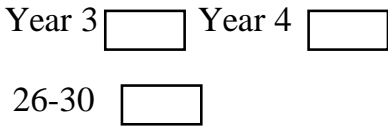

PART B

Please tick a number from 1-4 to indicate how important these skills are to you and also tick a number between 1-4 to indicate the extent to which these skills are emphasized in your school

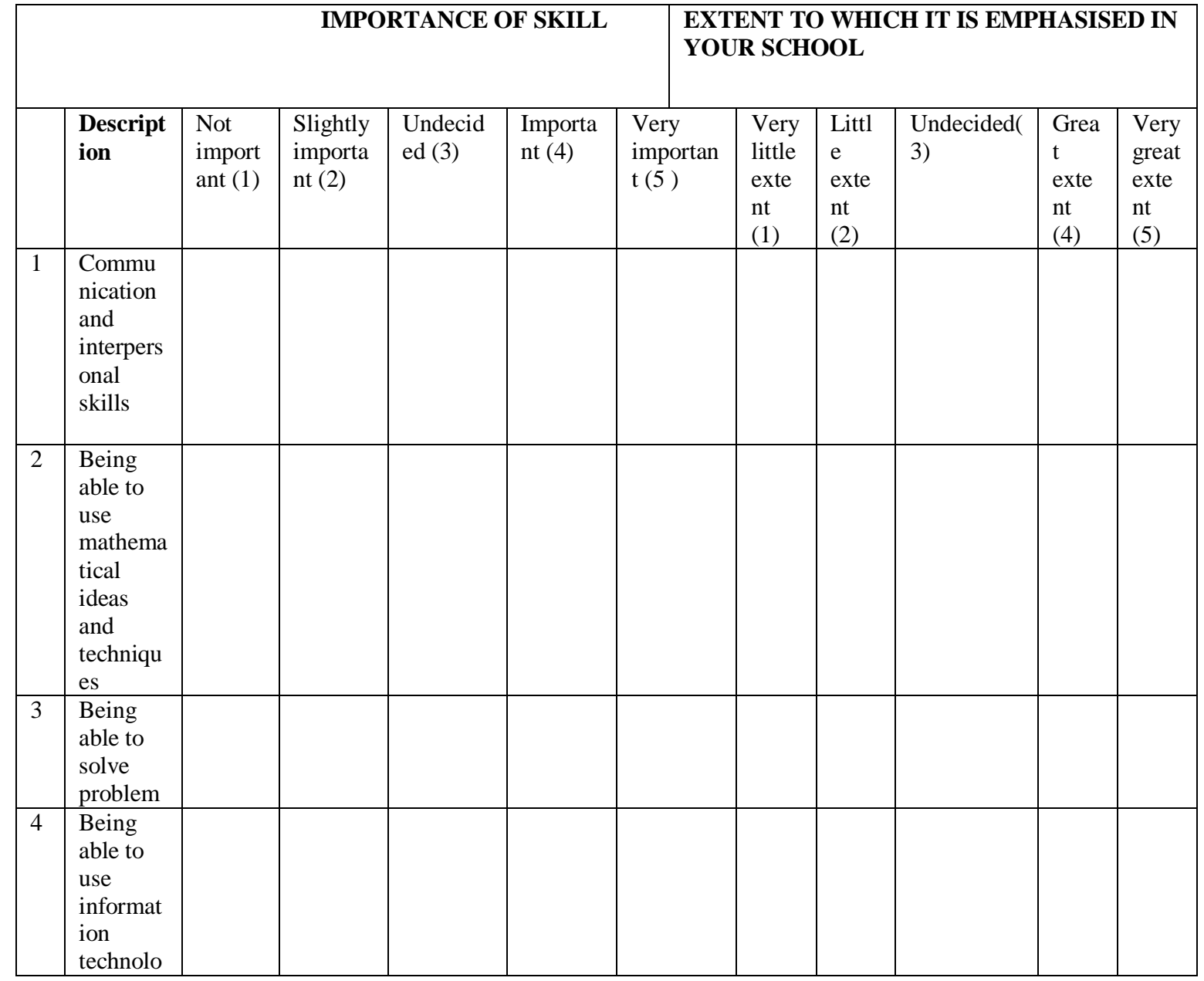




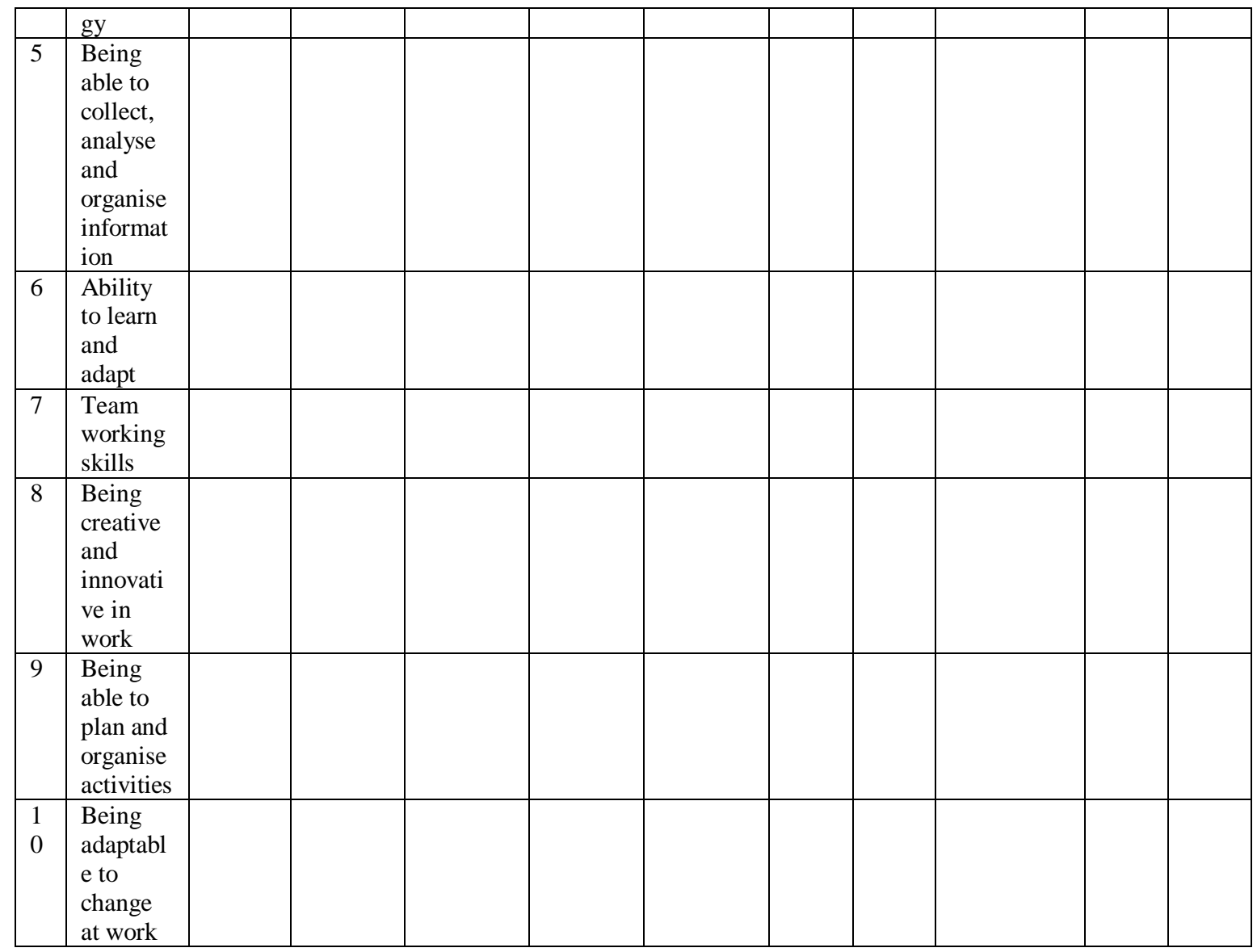

\section{SECTION B}

\section{Instruction}

Please you are required to respond to all the items in this questionnaire you are expected to indicate the extent of your agreement to the items by ticking $\square \square$ any of the options represented by the following Abbreviations

SA -

A -

$\mathrm{U}-$

$\mathrm{D}$ -

SD -
STRONGLY AGREE

AGREE

UNDECIDED

DISAGREE

STRONGLY DISAGREE

\begin{tabular}{|l|l|l|l|l|l|l|}
\hline $\begin{array}{l}\text { Item } \\
\text { No }\end{array}$ & Item description & $\begin{array}{l}\text { Strongly } \\
\text { Agree } \\
\text { (SA) }\end{array}$ & $\begin{array}{l}\text { Agree } \\
\text { (A) }\end{array}$ & $\begin{array}{l}\text { unde } \\
\text { cided } \\
\text { e (D) }\end{array}$ & $\begin{array}{l}\text { Disagre } \\
\text { Disagree } \\
\text { (SD) }\end{array}$ \\
\hline 11 & $\begin{array}{l}\text { The teacher divides the class into groups } \\
\text { during instruction sometimes }\end{array}$ & & & & & \\
\hline 12 & $\begin{array}{l}\text { Students sometimes comment on the } \\
\text { efforts of other students }\end{array}$ & & & & & \\
\hline 13 & $\begin{array}{l}\text { Students are assessed on -the- spot by } \\
\text { teachers after an activity }\end{array}$ & & & & & \\
\hline 14 & $\begin{array}{l}\text { Teachers use play-acting sometimes in } \\
\text { class }\end{array}$ & & & & & \\
\hline 15 & Mini projects are given by teachers & & & & & \\
\hline 16 & $\begin{array}{l}\text { Outside evaluation by other teachers } \\
\text { other than my teacher }\end{array}$ & & & & \\
\hline
\end{tabular}




\section{SECTION C}

\section{Instruction}

Please you are required to respond to all the items in this questionnaire you are expected to indicate the extent of your agreement to the items by ticking $\square \square$ any of the options represented by the following Abbreviations

SA -

A -

$\mathrm{U}-$

$\mathrm{D}$ -

SD -
STRONGLY AGREE

AGREE

UNDECIDED

DISAGREE

STRONGLY DISAGREE

\begin{tabular}{|l|l|l|l|l|l|l|}
\hline $\begin{array}{l}\text { Item } \\
\text { No }\end{array}$ & Item description & $\begin{array}{l}\text { STRON } \\
\text { GLY } \\
\text { AGREE } \\
\text { (SA) }\end{array}$ & $\begin{array}{l}\text { AGREE } \\
\text { (A) }\end{array}$ & $\begin{array}{l}\text { UNDECI } \\
\text { DED (U) }\end{array}$ & $\begin{array}{l}\text { DISAGR (D) } \\
\text { EE }\end{array}$ & $\begin{array}{l}\text { STRONGL } \\
\text { Y } \\
\text { DISAGRE } \\
\text { E (SD) }\end{array}$ \\
\hline 17 & $\begin{array}{l}\text { Provision of separate modules for teaching } \\
\text { generic skills }\end{array}$ & $\begin{array}{l}\text { Better promotion by teachers of the } \\
\text { importance of generic skills }\end{array}$ & & & & \\
\hline 19 & $\begin{array}{l}\text { More explicit profiling of generic skills } \\
\text { within the training packages }\end{array}$ & & & & & \\
\hline 20 & $\begin{array}{l}\text { Improvements on how generic skills are } \\
\text { explained and assessed }\end{array}$ & & & & & \\
\hline 21 & $\begin{array}{l}\text { Critical analysis and emphasis on the } \\
\text { importance and practice of generic skills } \\
\text { by teachers }\end{array}$ & & & & & \\
\hline 22 & $\begin{array}{l}\text { Professional/ adaptability skills } \\
\text { development of teachers }\end{array}$ & & & & & \\
\hline 23 & $\begin{array}{l}\text { Continued industry involvement in } \\
\text { training }\end{array}$ & & & & & \\
\hline 24 & Updating of existing training packages & & & & & \\
\hline
\end{tabular}

